\title{
Global Labor Practices And Corporate Social Responsibility
}

Bahaudin G. Mujtaba, (Email: mujtaba@sbe.nova.edu), Nova Southeastern University Frank J. Cavico, (Email: cavico@ huizenga.nova.edu), Nova Southeastern University Cyndy Jones, (Email: cyndyjones@bellsouth.net), Nova Southeastern University

\begin{abstract}
As companies work in the international marketplace, a level of corporate responsibility is expected by the international business community and by the consumers. Companies must set standards for operations that satisfy the expectations in the home country as well as the host countries. Multinational companies can no longer set financial goals in terms of sales and profitability as the only measures of success; but they must also set standards for ethical and socially responsible behavior of their own enterprise as well as their stakeholders. This paper, using Nike as an example, describes challenges associated with Corporate Social Responsibility (CSR) for large multinational organization. Furthermore, this paper discusses what Corporate Social Responsibility (CSR) is, and what is not, so managers can clearly and realistically state their goals and perspectives on what social responsibility means to their organizations and stakeholders.
\end{abstract}

\section{NIKE'S INTERNATIONAL CHALLENGES}

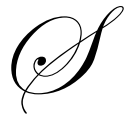

ocial responsibility is traditionally defined as taking an active part in the social, cultural, and charitable causes and the civic life of one's organization and community. While Nike has been very active internationally by providing work opportunities to various vendors and suppliers, the company has received much attention and criticism for these suppliers using low wage workers to produce Nike sneakers. It is apparent that much of Nike's initial success came from its determination to purchase sneakers from the lowest cost sources around the world, without any Foreign Direct Investment (FDI) in its own manufacturing plants. Furthermore, the company's success was associated with spending its resources on high-profile celebrities, such as Michael Jordan, to popularize the desire and demand for its products. The issue of low wages for foreign factory workers received even greater attention in the mid-1990s when an internationally known television celebrity by the name of Kathy Lee Gifford was accused of being a part of a clothing line that was made by "exploited" workers in developing nations. Kathy Lee Gifford took responsibility for enhancing factory conditions by joining the activists who provided much information on the reality of factory conditions and the exploitation of workers around the world, which served many of the American multi-national corporations (MNCs). Of course, Nike was featured in a good number of such media coverage on factory workers around the world; and the company was consistently associated with the exploitation of workers in the developing nations. While such associations might be real or simply perceived, these perceptions can, and did, impact Nike's image as not being a socially responsible firm. However, Nike has been battling such perceptions to bring about positive changes in the communities and plants producing their products, and to inform those who actually buy their sneakers.

The U.S. Supreme Court had agreed in January 2003 to decide if sneaker and apparel maker giant, Nike, was engaging in protected free corporate public affairs speech in a recent campaign to defend its business practices overseas (Cavico and Mujtaba, 2005). According to Cavico and Mujtaba, the eventual decision emerged as a significant court ruling, which tested the limits of the commercial speech doctrine, which can extend constitutional protection to a firm's marketing, promotional, and advertising activities designed to persuade consumers to buy products and services. 
The case revolved around Nike's massive advertising campaign to explain working conditions at its plants overseas in the face of allegations that the company's expensive products are made in sweatshops. Nike's troubles began when several media outlets ran stories about conditions in factories under contract with Nike in China, Vietnam, and elsewhere. The stories contended that the workers were paid below minimum wage, abused verbally and sexually, and exposed to dangerous working conditions, including working with hazardous chemicals.

San Francisco consumer activist Marc Kasky sued Nike, contending its advertising campaign to defend itself was inaccurate and deceptive. He especially took issue with statements by Nike chairman Philip H. Knight at a college appearance that Nike had the best factory conditions (Cavico and Mujtaba, 2005). Mr. Kasky also took issue with Nike's similar statements made to reporters and letters to editors and letters to college presidents and heads of athletic departments. Nike also took out full-page ads in college newspapers emphasizing the company's good corporate citizenship and humane labor standards. Certain company assertions, Mr. Kasky charged, including one that Nike paid more than double the minimum wage in countries where its products are produced, and another that workers are protected from physical to sexual abuse, amounted to false advertising. Mr. Kasky's suit also contend that Nike's statements that it provided free meals, housing, and healthcare to its workers were false, and that the workers' pay stubs actually showed that the company was deducting fees for those benefits.

A trial court in California agreed with Nike's contention that such statements were protected by the First Amendment right to free speech, and threw out Mr. Kasky's lawsuit; and a state appeals court upheld the ruling. However, in May of 2002, the California Supreme Court, in a split 4-3 decision, ruled that the company's efforts to defend itself before critics of its practices overseas amounted to mere "commercial speech," which applies when a company seeks to promote and defend its sales and profits and makes factual representations about its own products and operations (Cavico and Mujtaba, 2005). The California high court held that Kasky could sue Nike pursuant to a state consumer protection law because Nike's publicity was commercial speech, meaning the company could be sued for deceptive advertising. As opposed to political or public affairs speech, commercial speech, as determined by the U.S. Supreme Court, only is protected as free speech under the First Amendment if the speech is truthful and nondeceptive.

Over the recent years, the Supreme Court generally has granted commercial speech more First Amendment protection. Nonetheless, the line that separates commercial speech from non-commercial speech, especially political and public affairs speech, which are given the highest degree of First Amendment protection, is not clear. As a matter of fact, the California Supreme Court noted that commercial and non-commercial speech could be "inextricably intertwined" in Nike's statements defending its labor standards. Political speech typically concerns political campaigns as well as positions on public affairs issues, and has educational and informative purposes; whereas commercial speech, such as advertising, possesses the monetary motive to sell products and services.

The U.S. Supreme Court thus was asked to determine whether corporation's full free speech rights to defend themselves and their labor practices without fear of being sued for deceptive advertising. In addition to businesses and advertising agencies, some two dozen news organizations, fearing that lawsuits against companies would keep company executives from talking freely supported Nike in court filings. The U.S. Chamber of Commerce urged the Supreme Court to give companies more free speech protections. Supporters of the Kaksy suit, however, argued that rather than "chilling" protected speech, the decision will deter false, deceptive, and misleading speech. Nike asserted that if the Supreme Court does not overrule the California court, there could be a "flood" of lawsuits against companies for statements they made in the public debate in defense of their business practices.

However, surprisingly, despite the importance of the case, the U.S. Supreme Court, after hearing oral arguments, nonetheless dismissed the Nike case without a decision, thereby leaving the decision up to the California Supreme Court, which had ruled that a consumer group could sue Nike for false and deceptive advertising (Cavico and Mujtaba, 2005). As a result, Nike agreed to settle the lawsuit and to pay $\$ 1.5$ million to a workers' rights group, the Fair Labor Association, which will use the money to improve factory condition, strengthen workplace monitoring, and conduct worker programs. The Association, which was formed in 1999, promotes a conduct based on fair international labor standards, monitors labor practices, and makes public reports. Many legal and business people, however, had hoped that the U.S. Supreme Court would settle the speech issue; and the case was expected to set a 
major precedent, in particular to demarcate more clearly the distinction between public affairs speech and "mere" comment speech.

\section{NIKE'S INTERNATIONAL LABOR PRACTICES}

Historically speaking, Nike's CEO, Philip Knight adopted a unique two-pronged strategy for the organization (Barlett, Ghoshal, and Birkenshaw, 2004). According to a case entitled "Hitting the Wall: Nike and International Labor Practices" by Barlett, Ghoshal and Birkenshaw, the first prong of his strategy involved the complete outsourcing of all of its manufacturing to business partners in developing countries. The money saved by this approach would be focused on marketing through the use of high profile athletic celebrities. Nike's approach indicates that it has an international strategic mentality in that Nike sees itself as a domestic company with foreign partners working throughout the world.

Nike also believed this strategy would enable it to gain a competitive advantage by using the low cost labor pool in the developing countries. At first, Nike's manufacturing partners were located in Japan; and then shifted to Taiwan and Korea, because of the lower labor costs and production reliability. As the labor pool became more costly in those countries, Nike changed its partners again to companies in lower cost countries, such as Indonesia, China, and Vietnam.

Nike's strategy seemed very successful as it grew from a $\$ 60,000$ athletic shoe company to a $\$ 49$ billion multinational athletic shoe and apparel enterprise in ten years. However, in the 1990s, Nike, Inc found itself in a high profile scandal regarding the use of the low cost labor pool in developing countries. Nike's growth and reputation was jeopardized as it became the target of labor activists and then the global press as safety concerns, human rights violations and oppressive labor practices were uncovered in the factories of Nike's manufacturing partners.

In the early 1990's, daily wages in the Indonesian firms were reported to be approximately $\$ 1$ as compared to daily rates in South Korea at $\$ 24.40$ and $\$ 64$ in the United States. There were almost six times as many strikes in the Indonesian factories in 1991 as compared to 19 strikes in 1989. As the strikes continued, Nike was accused of encouraging its business partners to mistreat it workers through the use of low wages, long hours, unhealthy working conditions, and underage workers.

Nike insisted that it had no legal or moral responsibility for the actions of its independent contract partners. Nike maintained a very ethnocentric attitude in its approach to its contractors, but not setting standards for them. Unlike its competitors, however, eventually Nike did not embrace its corporate responsibility and respond to the charges. Nike did engage a newly hired public relations staff, Dusty Kidd, to develop a series of regulations for its contractors, called a Code of Conduct and Memorandum of Understanding and attached these as part of its new contracts.

Yet, these measures were not enforced and Nike continued to be criticized for worker exploitation in the U.S. media. Nike engaged Ernst and Young to conduct formal audits of the factories. Since Ernst and Young was paid by Nike, the reports were not considered to be objective, and consequently criticism against Nike continued.

In 1996, not only the US press, but the government began to investigate the area of child labor. Nike was the first company to join a Presidential task force to study the issue. It also established a Labor Practices Department to "help make things better for workers who make Nike products" (Bartlett et al., 2004, p.141).

In 1997, the negative press against Nike continued in popular cartoons, such as Doonesbury and national publications, such as the Wall Street Journal. Nike tried to ignore the rising criticism stating again that issue of wages was beyond its control. In the spring of 1997, a report by the Dartmouth's school of business was issued that suggested that companies such as Nike contribute to the growth of developing countries. Public opinion over the disparity between the daily labor rate of $\$ 1.67$ in Vietnam factories versus the $\$ 150$ price tag for a pair of Nike shoes, was very negative for Nike. When poor working conditions were revealed in a factory in Vietnam, Nike reported that these conditions had been addressed, resulting in even more criticism, as well as the California consumer lawsuit. 
Nike did not see any impact on its sales until late 1998 from this negative publicity. As can be seen in Figure 1 (Barlett, Ghoshal, and Birkenshaw, 2004), annual revenue declined in 1999. Nike denied that this downturn was related to its negative image; however Nike began to lose market share to its competitors and lost some of its major contracts with universities.

Figure 1: Nike Ten-Year Revenues Trend

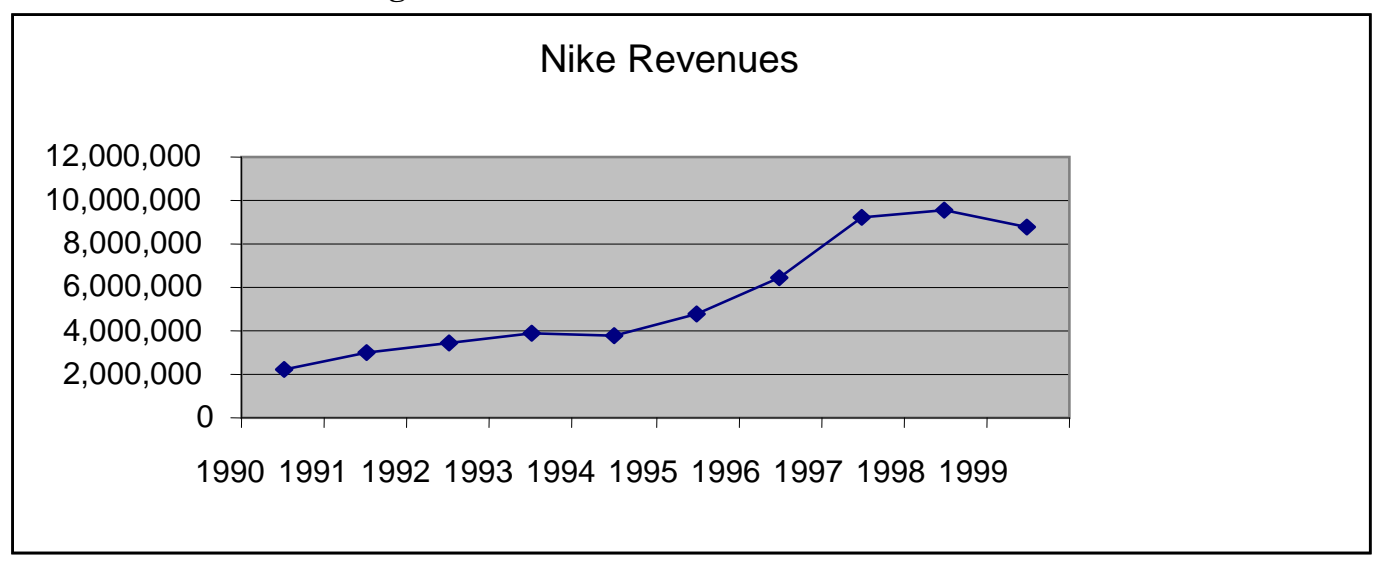

Finally, in 1998, Philip Knight introduced a series of reforms that included raising the minimal age of workers, adopting OSHA clean air standards, expanding its monitoring program, expanding worker educational programs, and making micro loans to workers. In addition, Nike became more involved in government-based reform efforts, including participation in the Apparel Industry Partnership. When this organization dissolved, Nike became active in the Fair Labor Association and worked to get other corporations involved with the organization.

In 1999, Nike ran extensive training programs for its contractor managers. All managers needed to learn the native language of the host country as well as to understand the cultural differences; and the company also worked with international organizations to improve the lives of the workers in the developing countries. These measures helped to improve Nike's image and reputation. However, even with these changes, Nike was criticized for not dealing with the real issue of minimum wage for workers.

\section{ALTERNATIVES, LIMITATIONS, AND CONSTRAINTS}

Multinational companies, like Nike, can no longer afford to ignore the global ramifications and responsibilities associated with its business activities. It is imperative for companies to understand the cultural profiles of the areas it operates. An analysis of two dimensions of the cultural profile: power distance and uncertainty avoidance for Nike is shown in Figure 2. "Power distance indicates the extent to which a society accepts the unequal distribution of power in institutions and organizations. Uncertainty avoidance refers to society's discomfort with uncertainty, preferring predictability and stability" (Bartlett et al., 2004, p.156).

As shown in Figure 2, Nike falls in the quadrant of low uncertainty avoidance and low power distance, indicating the need for less formalized rules and procedures, less hierarchical and more decentralized and people are free agents. Nike's contractors while they also fall in the low uncertainty avoidance category, the power distance is high. This fact indicates the need for a centralized, paternalistic structure where loyalty and personal relationships are important. 


\section{Figure 2: Cultural Profiles for Nike and Nike Contractors}

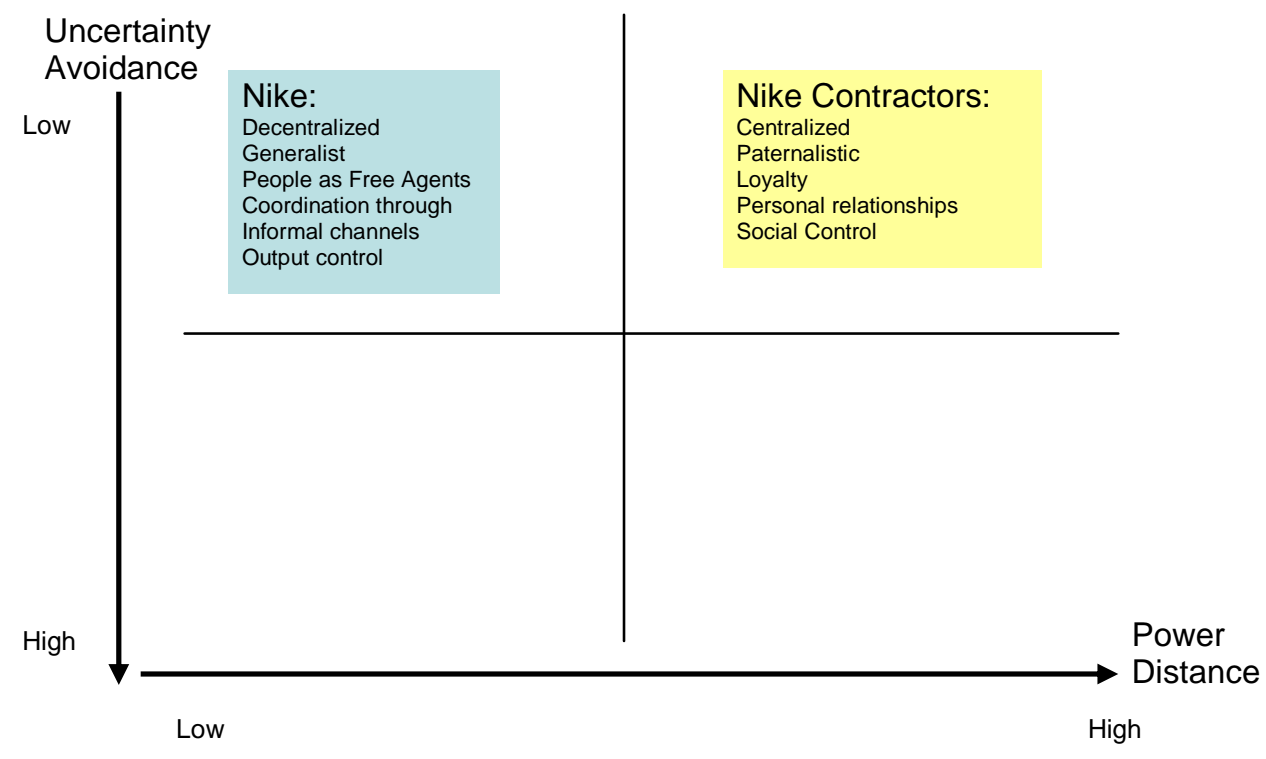

The implications for Nike is the need to have more formalized procedures and structures with its partners, and to develop more personal relationships with workers in the host countries.

While Nike did address many labor issues, it did not effectively deal with the issue of wages. In this area, Nike continued with its avoidance strategy. Throughout the early and middle 1990s, Nike denied any responsibility for the poor labor conditions in the manufacturing facilities. In 1992, the company's general manager in Jakarta said: "I don't know that I need to know" (Bartlett, et al., 2004, p.139). Nike did not consider that the labor and safety issues in the contractor factories were its responsibility. While this approach may be legally accurate, it was not well received by the "activist" community.

As shown in Figure 3, (Barlett, Ghoshal, and Birkenshaw, 2004), both the maximum and minimum monthly wage rate in rupiah increased from 1993 through 1997. When converted to dollars, as shown in Figure 4, using the effective exchange rate for each year, the daily rate in dollars decreased in 1996 and plummeted to less than $\$ 2.00$ in 1967. A study of wages in Vietnam indicated that the daily wage for an average worker was $\$ 1.67$. This compares to a daily rate of approximately $\$ 64$ for US workers.

Due to the measures that Nike did take to improve working conditions in the factories in the developing countries, its revenues as shown in Figure 5 did rebound in 2000, and continued to grow over the last several years. Nike's continued reluctance to deal with the labor wage, however, may continue to erode the image and reputation of the company. Nike accordingly needs to consider analyzing the compensation structures in the countries where its contractors operate. It needs to develop policies and procedures that provide compensation guidelines that are consistent with the industry and the host country standards.

\section{Recommendations for Nike}

Based on its experiences, Nike needs to recognize its status as a multinational company and move towards a more "transnational" mentality and to understand the importance to be flexible and responsive to country-level operations. In addition, Nike also needs to move to a more geocentric orientation and set global standards for its operations and develop greater identification with national interests of the host countries. 
Figure 3: Indonesian Monthly Wage Rates in Rupiah

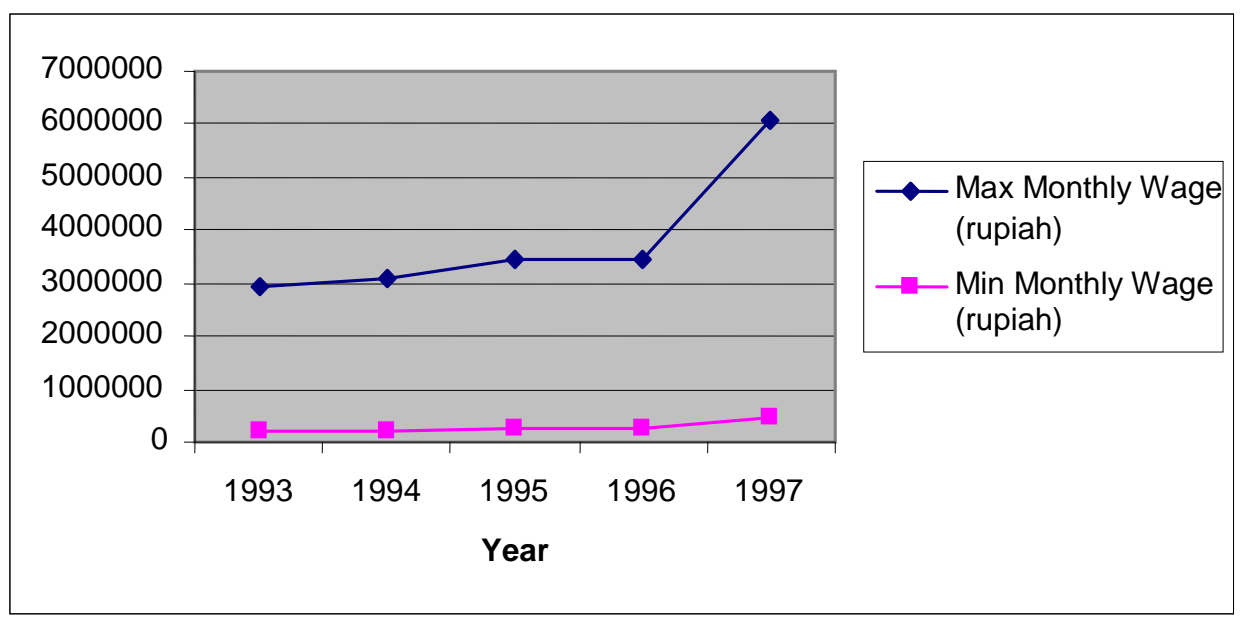

Figure 4: Indonesian Daily Wage Rates in Dollars

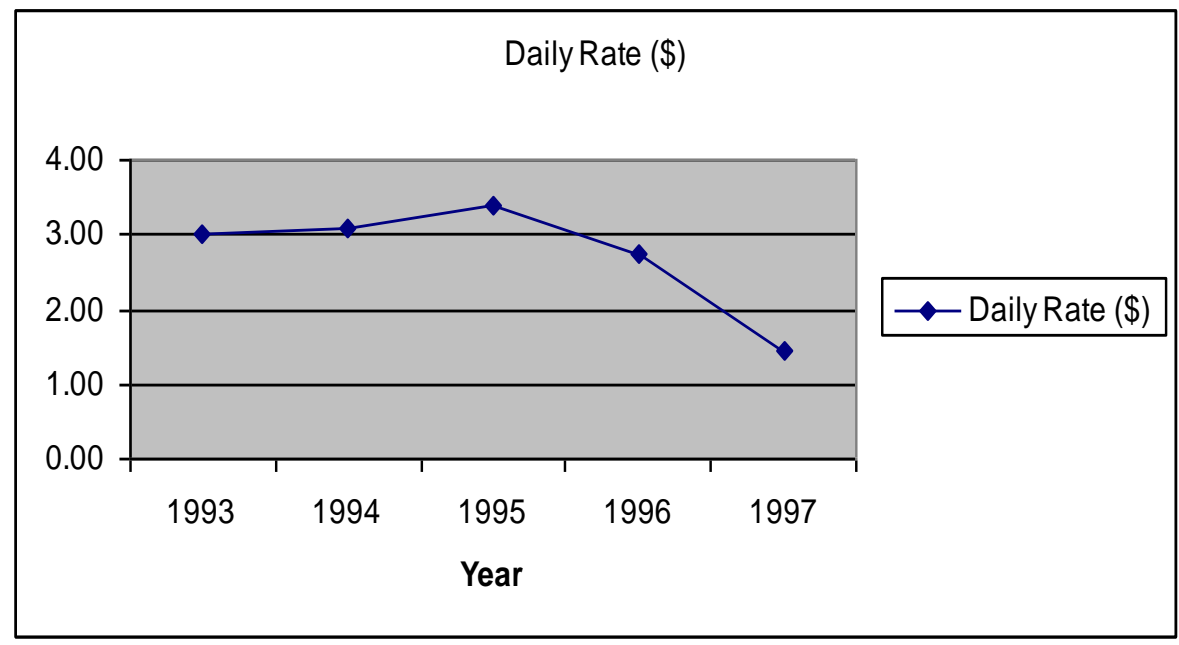

Figure 5: Nike Fifteen-Year Revenues Trend

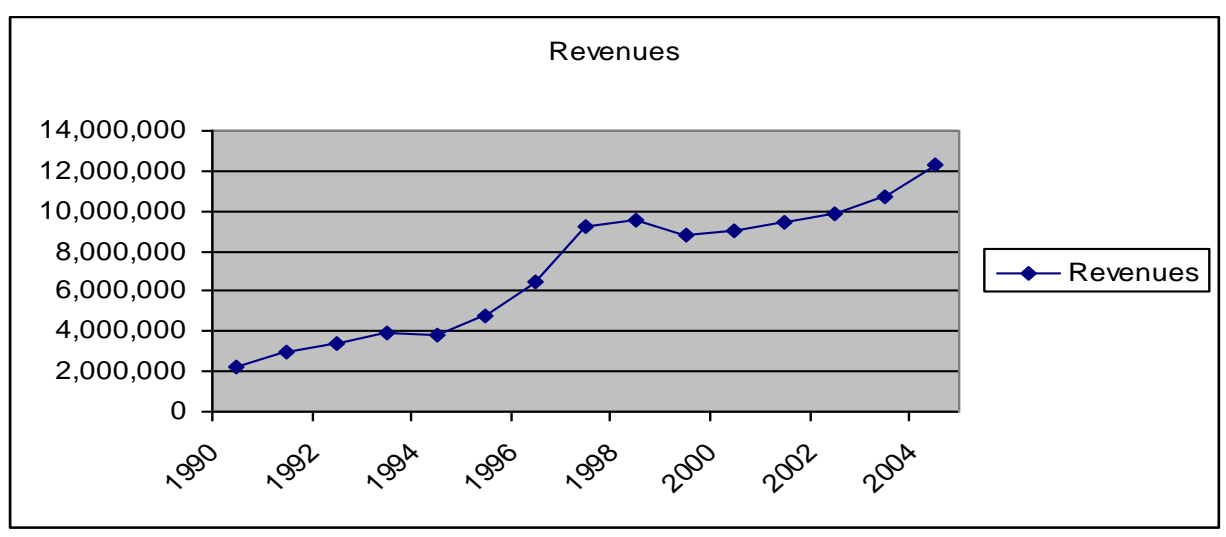


Nike, furthermore, needs to move from its internal-oriented and protectionist posture to an integrated business approach. Nike needs to develop more formalized procedures and structures that are adopted by its partners and to develop more personal relationships with workers in the host countries. Nike needs to continue to train its employees in these formal processes and procedures. Nike also needs to analyze compensation practices in the developing countries that it operates. Wage guidelines should be incorporated in the contracts with its manufacturing partners.

The major risk to these strategies is that there may be a decrease in profits in the short term. This result could be outweighed by the positive impact on Nike's reputation and image, which in turn may translate to greater sales and market share in the long term. Another risk that Nike may face is the instability of the governments in the region. This could be mitigated by a better understanding of the culture in the region and by developing personal relationships with government officials.

Since Nike outsourced all its manufacturing, strikes in any of its plants could adversely affect the supply chain in that goods may not be produced and delivered to fill customer orders on time. Nike's continuing efforts to improve labor conditions could mitigate this risk. Another mitigation strategy is for Nike to deal effectively with the wage issues of workers in the factories and to be viewed as a "socially responsible" organization. The remaining sections of this paper, therefore, discuss what corporate social responsibility (CSR) is, and what it is not, so national and multinational firms can clarify their position on this important subject.

\section{WHY FOCUS ON CORPORATE SOCIAL RESPONSIBILITY?}

The traditional purpose of business has been viewed to make money for the shareholders, in a legal manner, of course. The key values were thus economic and legal ones. Business was not supposed to be concerned with moral and social values. Not too long ago, with the advent of business ethics courses in schools of business as well as pressure from consumer, labor, and environmental groups, as well as the media, business has been compelled to deal with the moral implications of its actions. Accordingly, the values of ethics and morality became part of business school education as well as business policy and planning. Very recently, yet a new value, social responsibility has emerged to challenge business leaders and business educators. Social responsibility had not heretofore been viewed as a concern, let alone an obligation, of business. Yet, today, business is being forced to concern itself in a practical way with the social dimensions of its activities and the welfare of society as a whole, including global society. In order to examine this emergent and important issue, one first must ascertain what social responsibility is, and plainly what it is not.

\section{What Is Not Social Responsibility?}

Social Responsibility Is Not Legality

Legality, of course, is based on the law - treaties, constitutions, statutes, administrative rules and regulations, and cases. The law may require the performance of good deeds, for example, by requiring a contractor who wants to do business with the government to adopt an affirmative action program, or by requiring a bank to make investments in certain communities. These good deeds are premised on the force of the law; and thus are not "pure" social responsibility actions, but legal ones.

\section{Social Responsibility Is Not Morality}

Morality is based on ethics, which is a branch of philosophy. There are many ethical theories, containing ethical principles and precepts, which one can use to reason to moral conclusions of right and wrong and duty and obligation. Thus, could it not be argued that there is an ethical duty on the part of business to engage in social responsibility efforts and contributions? The Ethical Principle of Last Resort answers this question. According to this traditional ethical precept, a person, including a corporate "person," has a moral obligation to rescue and to aid, but only if certain conditions are met. These conditions are: the presence of a dire need or peril; proximity in time and space to effectuate a rescue; the capability to do so; one's position as the "last resort" or last real chance to avoid the 
harm or peril; and finally the rescuing or aiding would not cause harm equal to or greater than the original peril. When these conditions are all present then one has a moral duty to rescue. The classic example is the case of a drowning victim when the five factors are present. The problem in employing the "last resort" principle to business, particularly regarding corporate social responsibility, on an international scale, emerges as the fourth and fifth factors. Who is truly the last resort for people who are unemployed and in need - business or government? Government leaders elected by and accountable to the people, and not business leaders, are charged with advancing the general welfare. Moreover, would a corporation "rescuing" such people harm the corporation, its shareholders, or other stakeholders? One example is the case of the U. S. Malden Mills Company in New England, whose very compassionate owner rebuilt the facility after a fire without terminating any employees. Yet due in part to the added financial strain of keeping those employees, forced his company to file for Chapter 11 bankruptcy protection in order to reorganize his finances, thereby resulting in a considerably, and permanently, diminished workforce (Cavico and Mujtaba, 2005). Business, therefore, based on the Ethical Principle of Last Resort, typically will not be morally obligated to perform any social responsibility actions; and consequently business cannot be condemned as immoral for not performing such good actions.

\section{Social Responsibility Is Not Altruism}

According to Cavico and Mujtaba (2005), altruism is taking the interests of others into account in such a manner that one's intentions and actions afford some real degree of preference to others. Altruism consequently requires a substantial cost in time, effort, expenditure, and/or discomfort; it implies a degree of effacement of selfinterest, even sacrifice. For example, a member of a profession may be required to engage in altruistic behavior because the profession's code of ethics may demand such behavior. A person also may assume a particular role, such as a parent, that demands selfless devotion to the welfare of others. Business is neither required, nor expected, nor advised, to engage in altruistic behavior. Altruism is not social responsibility; and business is not expected by rational people to be altruistic.

\section{Social Responsibility Is Not Heroism}

A person is a hero if he or she performs an act or duty under circumstances in which almost all people would not perform the act or duty due to fear and the overwhelming interest in self preservation. Rescuing an assault victim from a knife-wielding bandit, or rescuing a distressed swimmer from shark-filled seas, would be examples of heroism. Heroism is not social responsibility; and no rational person can expect the business corporation to be heroic (Cavico and Mujtaba, 2005).

\section{Social Responsibility Is Not Sainthood}

Saint status (from a secular perspective for the purposes of this paper) involves great sacrifice. A person is deemed to be a "saint" if he or she does an act or performs a duty under circumstances in which personal inclination, desire, or self-interest would lead almost all people not to do the act or perform the duty. An organ donation to a stranger is an example of a saintly action (Cavico and Mujtaba, 2005). Similarly, a physician who gives up a lucrative practice to devote himself or herself totally to the impoverished people of a "third world" country can be called a saint. Saint status is not social responsibility; and no rational person can expect the business corporation to be saintly.

\section{What Is Social Responsibility?}

Now that one knows what social responsibility is not, what does this often used but admittedly ponderous term mean in a current global business context. Although business may not have a legal or moral responsibility to improve the quality of life in the community and society, business may be obligated by a standard of social responsibility to work for social as well as economic betterment. "Social responsibility," therefore, can be defined as taking an active part in the social, cultural, and charitable causes and civic life of one's organization, community, and society a whole (Cavico and Mujtaba, 2005). 


\section{Why Should A Company Be Socially Responsible?}

The social responsibility "obligation" of business suggests that global or national society may demand that business consider the social implications of its actions, and concomitantly to act in certain socially responsible ways. Otherwise, perhaps, society will compel business by international or legal mandate or increased taxation to fulfill its perceived social obligations. Business, as illustrated by the Nike case, also gains an improved public image by being socially responsible. An enhanced public image will attract more customers and investors, and thus provide positive benefits to the firm and its shareholders. Academic studies generally are supportive of the proposition that there exists a positive relationship between socially responsible behavior and favorable financial performance. Employees also may possess a heightened social consciousness, and consequently will want to be associated with a firm that not only is concerned with making profits but also with the welfare of society. A corporation that acts more socially responsible not only secures public favor, but also avoids public disfavor. Sir John Brown, the CEO of British Petroleum, astutely comprehends that society wants and expects business to be socially responsible. Social responsibility, at least in some reasonable degree, is thus in the long-term self-interest of business. Furthermore, a corporation cannot long remain a viable economic entity in a society that is uneven, unstable, and deteriorating. It thus makes good business sense for a company to devote some of its resources to social betterment projects. To operate efficiently, business needs educated and skilled employees. Education and training, therefore, should be of paramount interest to business leaders, and a company can center its social responsibility efforts in these critical areas. Finally, in recent years, there has been a steady growth of organizations that rate corporate social responsibility and that supply these ratings to investors and consumers. It obviously is beneficial to a company to earn a favorable corporate social responsibility rating. The conception of social responsibility as envisioned in this article merely asks business to take a longer-term, more expansive, stakeholder view of its traditional profit-maximization role (Cavico and Mujtaba, 2005). Enlightened self-interest and rational egoism, therefore, provide the justification for the firm's social responsibility efforts and contributions.

\section{How Should A Company Be Socially Responsible?}

There are many ways that business can fulfill its social responsibility obligation. A corporation, for example, can be socially responsible by providing computers to community schools and by releasing employees on company time to provide the training. British (BP), for example, markets itself as "Beyond Petroleum," and has been regarded as a very socially responsible firm for its global environmental and alternative fuel efforts. BP also is engaged in job training and building schools in the communities where it does business. Nike now offers small business loans to the family members of its employees. The pharmaceutical companies have been providing AIDS drugs at greatly reduced costs to African nations. Coca Cola has been using its extensive delivery system to transport the drugs to even the most remote African village. Pfizer loans a cadre of trained business and scientific professionals to aid groups in developing countries. Intel has computer clubhouses that provide Internet access and technology training to children in over 30 countries. General Electric is constructing hospitals in Ghana. Avon provides breast cancer programs and subsidizes mammograms in over 50 countries. Starbucks has built a health clinic in Guatemala. Home Depot is extensively involved with community efforts to develop and rehabilitate affordable housing. Office Depot has sponsored an international "best practices" conference on corporate giving. These are just a few of many examples of praiseworthy social responsibility contributions by business. Moreover, there is absolutely nothing wrong in a company's publicizing such social responsibility actions, and thereby receiving well-deserved acclaim.

\section{To What Degree Should A Company Be Socially Responsible?}

Regardless of how meritorious a firm's social responsibility actions may be, a company nonetheless must be careful in the degree of its commitment to the societal welfare. As to the proper extent of a company's social responsibility efforts and contribution, Aristotle has provided the answer. According to his seminal principle, the Doctrine of the Mean, Aristotle counseled that the correct and virtuous choice is a rationally determined mean between two extremes of deficiency and excess, which if present in a moderate degree will be a virtue. The intelligent and virtuous person will choose the mean between the two extremes, which constitute the corresponding vices. Accordingly, regarding the degree to which a company should be socially responsible, Aristotle would advise the firm not to concentrate on profits only, and abjure good deeds, because such deficiency is a vice. Similarly, Aristotle would 
advise the firm not to subordinate profits to good deeds, since too much attention to good deeds at the expense of profits is also a vice. Rather, Aristotle would counsel a company to aim for the mean of social responsibility, that is, profits first and then prudent good deeds (Cavico and Mujtaba, 2005). So, for example, "Chainsaw" Al Dunlap would represent the one extreme, and thus vice of deficiency in social responsibility. Ben \& Jerry's would represent the extreme and vice of excessive social responsibility. Such companies as Target, Hwelett-Packard, Proctor \& Gamble, Johnson \& Johnson, Coca Cola, Bank of America, and Microsoft would represent the virtuous means of moderate and prudent social responsibility. A corporation, of course, exists in a competitive global environment and thus is limited in its ability to solve the multitude of social problems. Business cannot and should not be expected to substitute for government or a "world government." If a corporation unilaterally or too generously engages in social betterment, it may place itself at a disadvantage when compared to other less socially responsible business entities. In a highly competitive market system, corporations that are too socially responsible may lessen their attractiveness to investors or simply may price themselves out of the market. The Ben and Jerry of Ben \& Jerry's, as a matter of fact, were forced by shareholders to accept a buy-out offer from Unilever, the multinational conglomerate. Yet a corporation that disdains any social responsibility, especially in a supercilious manner, may find itself less attractive to consumers and employees who likely will prefer to do business with and work for a socially responsible firm that provides good value. The Nike case clearly underscores the practical importance of prudent social responsibility.

\section{SUMMARY}

Can a global organization in the twenty first century environment afford not to be socially responsible? A short answer is "Not for long," as can be seen from Nike's case, since profiting from the international community must carry some obligations as well. Above and beyond the responsibility of business to act legally and morally is this very prevalent, undeniable, and practical issue of the social responsibility of business. The law determines legal accountability; philosophical ethics determines moral accountability; but ascertaining the definition, nature, and extent of social responsibility emerges as a serious challenge for today's business leaders, executives, and managers, especially in a global context. This task is certainly more than a mere "academic" one. Yet, if social responsibility is envisioned and accomplished in a right, proper, and moderate manner, as conceived in this paper, social responsibility is good business and thus "smart business"!

\section{REFERENCES}

1. Bartlett, C.A., Ghoshal, S. Birkenshaw, J. (2004). Transnational Management: Text, Cases and Readings in Cross-Border Management ( $4^{\text {th }}$ Edition). New York: McGraw/Irwin.

2. Business Week, 4/28/03, pp. 69-70.

3. Cavico, F. (July 2005). Corporate Social Responsibility: What's good for the community is good for business. SmartBusiness, Vol. 1, No. 11. Retrieved on July 20, 2005 from: http://broward.sbnonline.com/ marticle.asp?periodicalKey=23\&particleKey=9731

4. Cavico, F. \& Mujtaba, B., (January 2005). Business Ethics: Transcending Requirements through Moral Leadership. Pearson Custom Publications. U.S.A. ISBN: 0-536-85783-0. Web address: http://www. pearsoncustom.com/best/0536857830.html\#.

5. $\quad$ Czinkota, M.R., Tonkainen, I.A., Moffett, M.H. (2005). International Business ( ${ }^{\text {th }}$ Edition). Mason, Ohio: South-Western/Thomson Corporation.

6. Gardiner, L. Rubbens, C. Bonfiglioli, E. (2003). Big Business, Big Responsibility. Corporate Governance, 3, 3, 67-77. Retrieved May 20, 2005 from ABI/INFROM Complete.

7. Herald, 1/11/03, 4/24/03, pp. 1C, 3C, 4/28/03, p. 8B, 6/27/03, 9/13/03, pp. 1C, 2C.

8. Maigman, I., Ralston, D. (2002). Corporate Social Responsibility in Europe and the U.S.: Insights from Businesses' Self-presentations. Journal of International Business Studies, 33, 3, 497-514. Retrieved May 20, 2005 from ABI/INFROM Complete.

9. $\quad$ Sun Sentinel, 4/24/03, p. 3A.

10. Wall Street Journal, 6/30/03, 1/10/03. 